\title{
Aspek Hukum Pelanggaran Pada Perpres Nomor 54 Tahun 2010 Tentang Pengadaan Barang atau jasa Pemerintah
}

\author{
Adi Kadir \\ adikadir78@gmail.com \\ Program Studi Magister Hukum \\ Fakultas Hukum Universitas Airlangga Surabaya
}

\begin{abstract}
Abstrak
"Pengadaan Barang dan Jasa Pemerintah diatur pada Peraturan Presiden Nomor 4 Tahun 2015 tentang Perubahan Keempat atas Peraturan Presiden Nomor 54 Tahun 2010 tentang Pengadaan Barang dan Jasa Pemerintah, dan diubah dengan Peraturan Presiden No 16 Tahun 2018 " Pengertian Pengadaan Barang dan Jasa Pemerintah diatur pada kententuan Pasal 1 angka 1 Perpres No. 16 Th 2018; "Pengadaan Barang dan Jasa Pemerintah yang selanjutnya disebut Pengadaan Barang dan Jasa Pemerintah adalah kegiatan Pengadaan Barang dan Jasa Pemerintah oleh Kementerian/Lembaga/Kedudukan tinggkat Daerah yang didanai oleh APBN/APBD yang prosesnya sejak identifikasi kebutuhan, sampai dengan serah terima hasil pekerjaan."
\end{abstract}

Kata Kunci : Pengadaan Barang Dan Jasa, Aspek Hukum, Penegakkan Hukum.

\section{PENDAHLUAN}

Dalam usaha meningkatkan serapan

pembangunan dan pengembangan dalam negeri, pengembangan ini bertujuan untuk mendukung kinerja dari Pemerintahan itu sendiri baik berupa pembangunan dan jasa. ${ }^{2}$ “ Indonesia memberikan kewenangan Pemerintahan untuk melakukan peningkatan dan pengembangan baik infrastruktur maupun sumberdaya manusia, diperlukan kerjasama baik dengan Lembaga Pemerintah terkait maupun dengan perushaaan swasta dalam proyek pengembangan infrastruktur dan peningktan kualitas sumber daya manusia. Sejalan dengan cita-cita dalam Undangundang Dasar 1945 pada Pasal 33 tentang

1 https://bandung.bpk.go.id/files/2019/08/Pengadaan-BJ-Pemerintah-Perpres-16-2018.-2.pdf diakses pada tanggal 26 september 2019

${ }^{2}$ Marzuki yahya, endah susanti, aspek pengadaan barang dan jasa, sinar grafika, Jakarta 2012, h. 3 
demokrasi ekonomi, yang perwujudannya

berorientasi kepada rakyat. $^{3}$ Amanat

konstitusi melalui Pasal 33 ayat (4)

Undang-Undang Dasar 1945 berisi: "

diselenggarakan berdasarkan asas

demokrasi ekonomi dengan prinsip

kebersamaan, efisiensi kemandirian,

serta dengan menjaga keseimbangan

kemajuan dan kesatuan ekonomi

Nasional"

"Pengadaan Barang dan Jasa Pemerintah diatur pada Peraturan Presiden Nomor 4 Tahun 2015 tentang Perubahan Keempat atas Peraturan Presiden Nomor 54 Tahun 2010 tentang Pengadaan Barang dan Jasa Pemerintah, dan diubah dengan Peraturan Presiden No 16 Tahun 2018 ",

Pengertian Pengadaan Barang dan Jasa Pemerintah diatur pada kententuan Pasal 1 angka 1 Perpres No. 16 Th 2018;

"Pengadaan Barang dan Jasa Pemerintah yang selanjutnya disebut Pengadaan Barang dan Jasa Pemerintah adalah kegiatan Pengadaan Barang dan Jasa Pemerintah oleh Kementerian/Lembaga/Keduduka $\mathrm{n}$ tinggkat Daerah yang didanai oleh APBN/APBD yang

${ }^{3}$ Binoto Nadapdap, Hukum Persaingan Usaha, Jala Permata Aksara, Jakarta, 2009, h. 6

https://bandung.bpk.go.id/files/2019/08/Penga prosesnya sejak identifikasi kebutuhan, sampai dengan serah terima hasil pekerjaan."

"Pada Lembaga Pemerintahan yang mengadakan pengadaan barang dan jasa, pihak penyelenggara sangat mempengaruhi terhadap jalannya suatu proyek tersebut baik dalam penentuan nilai barang, dan hasil yang maksimal dalam proyek tersebut." 5 Dalam memenuhi kebutuhan pengelolaanya, “ Lembaga Pemerintah didanai oleh Negara yang diajukan dalam Anggaran Pendapatan Belanja Negara (APBN), hal tersebut diatur dimaksudkan agar dapat terpenuhinya efisiensi dan efektifitas pembelanjaaan yang dibutuhkan dalam pengelolaan lembaga Pemerintahan. Pengadaan adalah salah kegiatan yang dilakukan untuk pemenuhan kebutuhan tersebut. Pada suatu lembaga baik di Pemerintahan atau swasta memiliki barang yang

daan-BJ-Pemerintah-Perpres-16-2018.-2.pdf diakses pada tanggal 26 september 2019

5 http://www.djpbn.kemenkeu.go.id/por diakses pada tanggal 21 Septemer 2019 
digunakan untuk menyelesaikan dan menunjang pekerjaan yang ada di pada suatu lembaga atau lembaga tersebut barang penunjang yang berupa barangbarang inventaris. ${ }^{6 "}$

"Proses pengadaan barang atau jasa pemerintah dianggap sangat rentan akan adanya praktek korupsi, hal ini disebabkan setiap tahunnya nilai pengadaan barang atau jasa pemerintah selalu naik secara signifikan dengan dana yang dianggarkan untuk pengadaan barang atau jasa ini cukup besar."

"Terkait dengan proses pengadaan barang atau jasa tersebut, pada implementasinya terdapat salah satu unsur penting yang harus dibuktikan agar dapat dikualifikasi sebagai tindak pidana korupsi adalah adanya unsur dapat merugikan keuangan Negara atau perekonomian Negara".

${ }^{6}$ R. Serfianto DP, Iswi Hariyani, Buku Pintar Modal, Visimedia, Jakarta, 2007, h. 105

7 Dona Raisa Monica, Upaya Pencegahan Tindak Pidana Korupsi Pengadaan Barang Dan Jasa Melalui
Menurut Van Hamel, arti dari pidana atau straf menurut hukum positif dewasa ini adalah, ${ }^{8}$

"Een Bijzonder leed, tegen den overtreder van een door den staat gehandhaafd rechtsvoorschrift, op den enkelen grond van die overtrending, van wege den staat als hander openbare rechtsorde, door met de rechtsbedeeling belaste gezag uit te spreken." Artinya : "Suatu penderitaan yang bersifat khusus, yang telah dijatuhkan oleh kekuasaan yang berwenang untuk menjatuhkan pidana atas nama negara sebagai penanggung jawab dari ketertiban hukum umum bagi seorang pelanggar, yakni sematamata karena orang tersebut telah melanggar suatu peraturan hukum yang harus ditegakan oleh negara."

Pasal 1 KUHP mengatakan bahwa perbuatan yang pelakunya dapat dipidana atau dihukum adalah perbuatan yang sudah disebutkan didalam perundang-undangam sebelum

Penerapan Katalog Elektronik (E-Purchasing), Http://Jurnal.Fh.Unila.Ac.Id/Index.Php/Pidan a/Article/View/1206.

${ }^{8}$ Lamintang dan Theo Lamintang, Hukum Penitensier Indonesia, Sinar Grafika, Jakarta, 2012, h. 33. 
perbuatan itu dilakukan. ${ }^{9}$ Pengertian tindak pidana lainnya yaitu tindak pidana adalah setiap perbuatan yang mengandung unsur-unsur : perbuatan tersebut dilarang oleh undang-undang (mencocoki rumusan delik), memiliki sifat melawan hukum, dan tidak ada alasan pembenar

Penegakan hukum di Indonesia dilakukan secara pencegahan dan represif, adalah: ${ }^{10}$

\section{1. "Cara Pencegahan (Non Penal)}

Diadakan untuk mencegah agar tidak dilakukan pelanggaran hukum oleh masyarakat dan tugas ini pada umumnya diberikan pada badan eksekutif dan kepolisian."

\section{Cara Represif (Penal)}

"Dilakukan apabila usaha pencegahan telah dilakukan tetapi masih juga terdapat pelanggaran

9 Amir Ilyas, Asas-asas Hukum Pidana, Rengkang Education Yogyakarta dan Pukap Indomenisa, Yogyakarta, 2012, h. 28.

${ }^{10}$ Barda Nawawi Arief. Beberapa Aspek Kebijakan Penegakan Hukum dan hukum. Dalam hal ini, upaya yang dilakukan adalah secara represif oleh aparat penegak hukum yang diberi tugas yustisionil. Penegakan hukum represif pada tingkat operasional didukung dan melalui berbagai lembaga yang secara organisatoris terpisah satu dengan yang lainnya, namun tetap berada pada kerangka penegakan hukum.” "Banyak hal yang telah dilakukan oleh Pemerintah pada upaya pencegahan (non penal) pada tindak pidana korupsi khususnya di bidang pengadaan barang/jasa. Selain penanggulangan, yang perlu diperhatikan juga adalah dalam hal pengawasan terhadap pemerintahan dan pembangunan daerah dengan demikiankedudukanan Intelijen sangat sebagai Tim Pengawal dan Pengawasan Pemerintahan dan Pembangunan Daerah (TP4D).”

Pengembangan Hukum Pidana, Citra Aditya Bakti , Bandung 2005, h. 22 
"TP4D disusun sesuai dengan tugas

dan wewenang Kejaksaan Republik Indonesia adalah mencegah terjadinya tindak pidana korupsi yang telah tertuang pada Instruksi Presiden Nomor 7 Tahun 2015 tentang Aksi Pencegahan dan Pemberantasan Korupsi, antara lain bertujuan untuk meningkatkan upaya Pencegahan terjadinya tindak pidana korupsi di Pemerintah Pusat/ Kementerian/ Lembaga/ Pemerintah Daerah/ BUMN/ BUMD yang perlu didukung dan dijalankan secara terencana, komprehensif, sungguhsungguh dan memberi manfaat sehingga kegiatan Pencegahan korupsi yang dilakukan oleh Kejaksaan Republik Indonesia berlangsung secara efektif dan optimal.”

"Keberadaan TP4 harus menjadi pendorong semakin tingginya kepercayaan diri pelaksana Pengadaan Barang atau jasa Pemerintah pada menjalankan tugas. Karena ada tempat bertanya, meminta saran tindak hukum bahkan berlindung dari intervensi dan intimidasi. Termasuk juga meminimalisir kemungkinan niat jahat yang dapat merugikan keuangan Negara.”

\section{Peraturan Menteri Pada Negeri} Republik Indonesia Nomor “33 Tahun 2017 Tentang Pedoman Penyusunan Anggaran Pendapatan Dan Belanja Daerah Tahun Anggaran 2018 mengisyaratkan bahwa leading sektor pada kerjasama dengan TP4D adalah Inspektorat Daerah. Di beberapa daerah dibungkus pada kegiatan sinergitas pengawasan Pembinaan dan Pengawasan Penyeleggaraan Pemerintahan Daerah. Salah satu hal yang harus tegas dan jelas pada persetujuan kerjasama pengawalan dan pengamanan Pengadaan Barang atau jasa Pemerintah adalah pada tahapan-tahapan mana saja diperlukan kehadiran TP4D." "Berdasarkan pada uraian latar belakang masalah di atas, maka masalah yang akan dibahas pada penelitian ini, adalah, Perumusan masalah dibuat dengan tujuan untuk memecahkan masalah pokok yang timbul secara jelas dan sistematis. Perumusan masalah ini digunakan untuk menegaskan masalah 
yang akan diteliti, sehingga lebih memudahkan dalam penelitian yang dilakukan dan sesuai sasaran yang diterapkan. Berdasarkan uraian di atas, permasalahan yang akan di kaji dalam penelitian ini sebagai berikut : Bagaimana Aspek Hukum Pelanggaran Pada Perpres Nomor 54 Tahun 2010 Tentang Pengadaan Barang atau jasa Pemerintah

\section{METODE PENELITIAN}

"Melalui penelitian yuridis normatif dengan pertimbangan bahwa titik tolak penelitian analisis terhadap peraturan perundang-undangan pada kerangka hukum nasional Indonesia sendiri. Maka tipe penelitian yang digunakan adalah penelitian juridis normatif, yakni penelitian yang difokuskan untuk mengkaji penerapan kaidah kaidah atau norma-norma pada hukum positif, ${ }^{11}$ khususnya mengenai pengaturan tugas Kejasaan RI sebagai TP4D sebagai

11 Peter Mahmud Marzuki, Penelitian Hukum, Kencana Prenada Media Group,Jakarta, 2005, h.171. upaya pencegahan dan penangganan tindak pidana korupsi pada pembangunan daerah." "Pada penelitian ini menggunakan Pendekatan perundang-undangan (statute approach), Pendekatan konseptual (conceptual approach). Pendekatan perundang-undangan (statute approach) Pendekatan perundangundangan (statute approach) dan Pendekatan konseptual (conceptual approach). Pendekatan perundanganundangan (statute approach) diperlukan guna mengkaji lebih lanjut mengenai dasar hukum. Pendekatan undang-undang dilakukan dengan menelaah semua undang-undang dan regulasi yang bersangkut paut dengan isu hukum yang sedang ditangani ${ }^{12}$.

Dalam penelitian ini juga menggunakan pendekatan konseptual (conceptual approach) ${ }^{13}$ pendekatan

12 Peter Mahmud Marzuki. Penelitian Hukum. (Jakarta:Kencana Prenada Media Group, 2009). h. 93.

${ }^{13}$ Ibid,. 
yang beranjak dari pandanganpandangan dan doktrin-doktrin yang berkembang didalam ilmu hukum. Dengan menelaah pandanganpandangan dan doktrin-doktrin tersebut dengan penafsiran sistematisasi terhadap bahan-bahan hukum tertulis agar diperoleh hasil analisa hukum, yang dimaksud pendekatan konsep di sini adalah pendekatan dengan memahami konsep-konsep yang diajukan dalam permasalahan pendekatan yang penulis lakukan adalah pendekatan terhadap Undang-undang terkait, diantaranya adalah Undang-undang nomor 16 tahun 2004 tentang Kejaksaan Republik Indonesia, Undang-Undang Nomor 20 Tahun 2001 tentang Perubahan atas Undang-Undang Nomor 31 Tahun 1999 tentang Pemberantasan Tindak

\footnotetext{
${ }^{14}$ Robertson, Crimes Against Humanity, 90; see "analytical jurisprudence" for extensive debate on what law is; in The Concept of Law Hart argued law is a "system of rules" (Campbell, The Contribution of Legal Studies,
}

Pidana Korupsi , Peraturan Jaksa Agung No. : PER-009/A/JA/01/2011 tentang Organisasi dan Tata Kerja Kejaksaan Republik Indonesia. Pendekatan konseptual (conceptual approach), yang dimaksud pendekatan konsep di sini adalah pendekatan dengan memahami konsep-konsep yang diajukan pada permasalahan seperti asas hukum umum."

\section{PEMBHASAN}

\section{a. Aspek Hukum Pelanggaran Pada Perpres Nomor 54 Tahun 2010 Tentang Pengadaan Barang atau jasa Pemerintah}

"Hukum merupakan suatu
sistem yang penting pada
pelaksanaan rangkaian kewenangan
dan kekuasaan kelembagaan Negara
dan Pemerintah pada aspek yang
sempit. ${ }^{14 "}$

184); Austin said law was "the command of a sovereign, backed by the threat of a sanction" (Bix, John Austin); Dworkin describes law as an "interpretive concept" to achieve justice (Dworkin, Law's Empire, 410); and Raz argues 


$$
\text { "Kemungkinan terjadinya }
$$

tindak pidan akorupsi pada

Pengadaan Barang atau jasa

Pemerintah pemerintah, yang telah

disebut pada UU No. 31 Tahun 1999

juncto UU No. 20 Tahun 2001

tentang Tindak Pidana Korupsi, antara lain $;^{15}$

a. Pemberian

Suap,

Penggelapan

Memberi pada bentuk uang, barang, fasilitas, dan janji

untuk melakukan atau tidak

melakukan suatu perbuatan

yang akan berakibat kepada

diri sendiri atau pihak lain

yang berhubungan dengan

jabatan yang dipegang.

Pengelapan merupakan

perbuatan mengambil tanpa

hak oleh seseorang yang

telah diberi kewenangan

law is an "authority" to mediate people's interests (Raz, The Authority of Law, 3-36).

15 Suparman, Eman, Aspek Hukum

Perdata dalam Pelaksanaan Pengadaan Barang/Jasa Pemerintah Dinamika serta untuk mengawasi dan

bertanggung jawab penuh

terhadap barang milik

Negara oleh pejabat publik

baik swasta.

b. Pemalsuan, Pemerasan

Pemalsuan adalah tindakan

atau perilaku untuk

mengelabui orang lain atau

organisasi dengan maksud

untuk keuntungan dan

kepentingan dirinya sendiri

baik orang lain. Pemerasan

adalah suatu perbuatan

dengan memaksa seseorang

untuk membayar atau

memberikan sejumlah uang

atau barang, atau bentuk lain

sebagai ganti dari seorang

pejabat publik untuk berbuat

atau tidak berbuat sesuatu.

c. Penyalahgunaan Wewenang

Potensi Penyalahgunaan Wewenangnya (Seminar Nasional tentang Pengadaan Secara Elektronik Dalam Rangka Pencegahan Tindak Pidana Korupsi). Rabu, 8 Maret, Fakultas Hukum UNIKOM, Bandung, h. 23 
Mempergunakan

kewenangan yang dimiliki

untuk melakukan tindakan

yang memihak atau pilih

kasih kepada kelompok atau

perseorangan; bersikap

diskriminatif terhadap

kelompok atau

perseorangan lainnya.

d. konflik Kepentingan

(Sumbangan Ilegal)

Hal ini terjadi apabila partai

politik atau pemerintahan

yang sedang berkuasa

menerima sejumlah dana

sebagai kontribusi dari hasil

yang dibebankan kepada

kontrak-kontrak Pengadaan

Barang atau jasa Pemerintah

pemerintah.”

"Kemungkinan-kemungkinan

terjadinya tindak paoidan korupsi

seperti yang diuraikan di atas juga
16 Sutedi, Adrian, Aspek Hukum Pengadaan Barang/Jasa Pemerintah dengan ditegaskan pada UU No. 31 Tahun 1999 jo UU No. 20 Tahun 2001 tentang Tindak Pidana Korupsi. Perbuatan seperti menerima hadiah, komisi, atau menghimpun dana dapat dikategorikan sebagai perbuatan korupsi. Pada Bab II undang-undang tersebut, diatur berbagai perbuatan yang dapat digolongkan sebagai tindak pidana korupsi. ${ }^{16}$

"Kontrak pengadaan sebagai dasar perikatan antara penyedia barang atau jasa dengan pengguna barang/jasa yang diwakili oleh pejabat pembuat komitmen. Pengadaan Barang atau jasa Pemerintah juga termasuk pada ruang ranah Hukum Administrasi Negara dan Hukum Pidana. Pelaksanaan Pengadaan Barang atau jasa Pemerintah memiliki banyak kemungkinan untuk terjadinya pelanggaran terhadap peraturan

Berbagai Permasalahannya, Sinar Grafika, Jakarta, 2012, h. 25 


$\begin{array}{lrlrl}\text { perundang-undangan. } & \text { Mulai } & \text { kemungkinan } & \text { untuk } & \text { terjadinya } \\ \text { penyalahgunaan } & \text { wewenang, } & \text { pelanggaran-pelanggaran } & \text { terhadap }\end{array}$
perbuatan melawan hukum peraturan perundang-undangan. sampai (onrechmatigedaad) sampai tindak tindak pidana korupsi. Bentuk pidana korupsi. Konsekuensinya, pertanggungjawabannya dapat diberikan organisasi Pengadaan Barang atau sanksi berupa tuntutan ganti rugi, sanksi jasa Pemerintah memiliki tanggung administratif, dan sanksi pidana. Pada jawab sebagai pegawai negeri dan Pengadaan Barang atau jasa Pemerintah sebagai personal. Bentuk pemerintah, terdapat kontrak pengadaan pertanggungjawabannya dapat sebagai dasar perikatan antara penyedia diberikan sanksi berupa tuntutan ganti rugi, sanksi administratif, dan sanksi pidana itu sendiri."

\section{KESIMPULAN}

"Berdarskan sumber dana yang digunakan pada proses Pengadaan Barang atau jasa Pemerintah berasal dari dana APBN/APBD, Pada prinsipnya, Pengadaan Barang atau jasa Pemerintah merupakan kewenangan ruang ranah Hukum Perdata proses Pengadaan Barang atau jasa Pemerintah juga termasuk dalam ranah Hukum Administrasi Negara dan Hukum Pidana. Pelaksanaan Pengadaan Barang atau jasa Pemerintah memiliki banyak barang atau jasa dengan pengguna barang/jasa yang diwakili oleh pejabat pembuat komitmen. Kebijakan yang dilakukan oleh TP4 yang pada kebijakan tersebut disusun oleh TP4 untuk melaksanakan rangkaian kegiatan pengawalan, dan pengaman pada pekerjaan-pekerjaan strategi nasional untuk tujuan khsuus adalah sebagai upaya mencegah timbulnya tindak pidana korupsi."

\section{DAFTAR PUSTAKA}

\section{"BUKU}

Abdul Halim dann Syam Kusufi, Teori Konsep dan Aplikasi Akuntansi Sektor Publik Dari Anggaran Hingga Laporan Keuangan dari 
Pemerintah Hingga Tempat Ibadah, SAlemba Empat , 2013

Adrian Sutedi, Aspek Hukum Pengadaan Barang dan Jasa serta Berbagai Permasalahannya, Sinar Grafika, Jakarta, 2008

Adami Chazawi, Pelajaran Hukum Pidana, PT. Raja Grafindo Persada, Jakarta, 2004,

Andi Hamzah, KUHP \& KUHAP, Rineka Cipta, Jakarta, 2011,

AR. Mustopadidjaya, Manajemen Proses Kebijakan Publik, Formulasi, Implementasi dan Evaluasi Kinerja: Jakarta:LAN, 2002

Binoto Nadapdap, Hukum Persaingan Usaha, Jala Permata Aksara, Jakarta, 2009

Burhanudin, Prosedur Hukum Pengurusan Bea dan Cukai, Pustaka Yustisia, Yogyakarta, 2013,

Barda Nawawi Arief, Beberapa Aspek Kebijakan Penegakan Hukum dan Pengembangan Hukum Pidana, Citra Aditya Bakti, Bandung, 2005

Chairul Huda, Dari Tiada Pidana Tanpa Kesalahan Menuju Kepada Tiada Pertanggungjawaban Pidana Tanpa Kealahan. Tinjauan Kritis Terhadap Teori Pemisahan Tindak Pidana dan Pertanggungjawaban Pidana. Kencana Prenada Media, Jakarta.2006

Dona Raisa Monica, Upaya Pencegahan Tindak Pidana Korupsi Pengadaan BArang dan Jasa Melalui Penerapan Katalog Elektronik (Epurchasing).

Hendi Suhendi, Muhammad Iqbal, Nisya, Meryana Andriani, Penguatan
TerhadapEfektifitas Tugas dan Wewenang Tim Pengawal, Pengaman Pemerintah dan Pembangunan (TP4) Sebagai Upaya Pencegahan Tindak Pidana Korupsi, Mizwar, Jakarta, 2017

Marzuki yahya, endah susanti, aspek pengadaan barang dan jasa, sinar grafika , Jakarta 2012,

Moeljatno, Asasasas Hukum Pidana, Rineka cipta,Jakarta, 2015,

Mohammad Taufik Makarao dan Suhasril, Hukum Acara Pidana dalam Teori dan Praktek, Ghalia Indonesia, Bogor, 2010,

Moh.Hatta, Beberapa Masalah Penegakan Hukum Pidana Umum \& Pidana Khusus, Yogyakarta. Liberty Yogyakarta: 2009

Muladi, Kapita Selekta Sistem Peradilan Pidana. Badan Penerbit Universitas Diponegoro, Semarang. 1995

Peter Mahmud Marzuki, Penelitian Hukum, Kencana Prenada Media Group,Jakarta, 2005,

R. Serfianto DP, Iswi Hariyani, Buku Pintar Modal, Visimedia, Jakarta, 2007 ,

Satjipto Raharjo,Masalah Penegakan Hukum : Suatu Tinjauan Sosiologis, Sinar Baru, Bandung, 2004,

S.R. Sianturi, Asas-asas Hukum Pidana di Indonesia dan Penerapan, Cet. 3, Jakarta Storia G

rafika, 2018,

Sudarto, Hukum Pidana I, Semarang: Yayasan Sudarto, 1990, 
Suharto dan Junaidi Efendi,Panduan Praktis Bila Menghadapi Perkara Pidana, Mulai Proses Penyelidikan Sampai Persidangan, Jakarta, Prestasi Pustaka, 2010,

Russel Butarbutar, Pertanggungjawaban Korporasi Dalam Tindak Pidana Korupsi Pengadaan Barang dan Jasa Pemerintah Di Bidang Konstruksi, Bekasi,Gratama Publishing, 2015,

Tri Andrisman, Asas-Asas dan Dasar Aturan Hukum Pidana Indonesia, BandarLampung, Unila, 2009

Teguh Prasetyo, 2010, Hukum Pidana, Jakarta: Rajawali Press, 2010,

Wirjono Projodikoro, Asas-Asas Hukum Pidana di Indonesia, Refika Aditama, Bandung,2003

\section{WEBSITE}

https://bandung.bpk.go.id/files/2019/08/Pe ngadaan-BJ-Pemerintah-Perpres16-2018.-2.pdf diakses pada tanggal 26 september 2019 http://www.djpbn.kemenkeu.go.id/por diakses pada tanggal 21 Septemer 2019

https://bandung.bpk.go.id/files/2019/08/Pe ngadaan-BJ-Pemerintah-Perpres16-2018.-2.pdf

Setyo, Utomo, Pencegahan tindak pidana korupsi,https://www.academia.ed u/29104905/PENCEGAHAN_TI NDAK_PIDANA_KORUPSI_PA DA_JASA_KONSULTASI_1

Panduan Teknis Kpa , https://djpb.kemenkeu.go.id/porta 1/images/panduan_teknis/kpa/Pan duan-Teknis_KPA_Final.pdf

http://www.lkpp.go.id/v2/files/download/3 /Paket-1.pdf

https://kejari-

saburaijua.kejaksaan.go.id/tp4dtim-pengawal-dan-pengamanpemerintah-dan-pembangunandaerah/ diakses pada tanggal 10 Oktober 2019

http://www.kejarijakbar.go.id/index.php/tp4d/penge rtian diakses pada tanggal 16 Oktober 2019 